\title{
COMMENTS
}

\section{A Systematic Approach to Privilege Against Self-Incrimination Claims When Foreign Prosecution Is Feared}

\author{
Scott Bovino†
}

The Fifth Amendment prohibits authorities from compelling a witness to give testimony that might be used to incriminate him. ${ }^{1}$ Nevertheless, the witness may be required to testify if the authorities demonstrate that the testimony they seek could not be used against him. ${ }^{2}$ Usually when authorities desire self-incriminating testimony, they offer a witness use-derivative-use immunity: that is, immunity from use of the testimony, or any evidence derived from the testimony, that would aid in his criminal prosecution. If a witness claims that his testimony would incriminate him under foreign law, however, the grant of use-derivative-use immunity may not alleviate concerns of testimony-aided prosecution, because a foreign government is under no obligation to honor a grant of immunity that derives its power from domestic law. In foreign prosecution cases, moreover, the American trial judge will be unable to determine if the witness is entitled to invoke the privilege against

$\dagger$ B.A. 1988, Franklin \& Marshall College; M.S. 1991, Stanford University; J.D. 1993, The University of Chicago.

${ }^{2}$ US Const, Amend V ("No Person . . . shall be compelled in any criminal case to be a witness against himself . . . "). See also Murphy $v$ Waterfront Commission of New York Harbor, 378 US 52, 79 (1964) (a "witness may not be compelled to give testimony which may be incriminating . . . unless the compelled testimony and its fruits cannot be used in any manner . . . in connection with a criminal prosecution against him").

* See Kastigar v United States, 406 US 441, 453 (1972). 
self-incrimination, since the judge may not understand the applicable foreign law.

To address these complications, the federal courts have sought to apply traditional privilege against self-incrimination principles to foreign prosecution cases by requiring witnesses to suggest how their testimony might incriminate them under foreign law, and by providing witnesses with forms of protection allegedly commensurate with domestic immunity. Yet in practice, these adaptations of traditional principles have resulted in numerous additional burdens being placed on witnesses seeking protection from the privilege. Because fears of foreign prosecution cannot readily be alleviated by conferring use-derivative-use immunity, the federal courts have sought to place greater burdens on witnesses fearing foreign prosecution in order to guard against fabricated fears and preserve the ability of domestic authorities to acquire important information from such witnesses. However, the unprincipled means chosen by the federal courts to dispose of foreign prosecution claims has led to the compulsion of testimony under arguably unjustified circumstances.

This Comment describes a methodology that judges can follow in all privilege against self-incrimination cases, and explains how differences in the treatment of witnesses fearing foreign prosecution might be appropriately instituted. The discussion assumes that the privilege may be invoked by witnesses fearing foreign prosecution because an important purpose of the Fifth Amendment is to protect against the intrusions on dignity and privacy that accompany compulsory self-incrimination. The Comment however, ultimately suggests that the scope of this protection should be narrower than that afforded in domestic prosecution cases because testimony-aided prosecution by a foreign government does not offend another fundamental purpose of the Fifth Amendment: to prevent domestic authorities from using a witness's compelled testimony against him.

Section I of the Comment outlines both the traditional approach to privilege against self-incrimination claims and the different considerations that arise in foreign prosecution cases. Section II summarizes the foreign prosecution jurisprudence of the Supreme Court and the Courts of Appeals, illustrating three ways in which these courts have failed to provide witnesses fearing foreign prosecution with protection equal to that afforded in domestic prosecution privilege against self-incrimination cases. Finally, Section III discusses the common elements of all privilege against selfincrimination cases, and suggests how these elements should be 
viewed when foreign prosecution is feared. This Section concludes by proposing that foreign prosecution claims should be evaluated on a case-by-case basis, with the extent of protection a witness receives depending on a balancing of the government's interests in obtaining the testimony against society's interest in preventing compulsory self-incrimination.

\section{The Basic Privilege Against Self-Incrimination Inquiry}

As a general rule, if a witness's testimony cannot be used to further his criminal prosecution, compelling the witness to testify does not violate his privilege against self-incrimination. ${ }^{3}$ Under the traditional approach to the privilege, there are two ways to show that testimony-aided prosecution will not occur. First, one may show that both the requested testimony, and any evidence that might be derived from this testimony, could not provide "a link in the chain of evidence needed to prosecute the [witness]." Second, the witness may be provided with alternative forms of protection-like use-derivative-use immunity-against the use of his testimony, or any evidence derived from it, in furtherance of his criminal prosecution. ${ }^{5}$

At least two complications can arise, however, when the governmental authorities seeking to compel testimony operate in a jurisdiction other than the one in which prosecution might later occur. First, the trial judge evaluating the witness's claim to the privilege may be unfamiliar with the criminal laws of the prosecuting jurisdiction or the application of these laws to the witness's claim. Second, traditional forms of alternative protection against testimony-aided prosecution, particularly use-derivative-use immunity, may be ineffective or unavailable in the prosecuting jurisdiction.

This Section describes how courts determine whether a witness claiming protection under the privilege against self-incrimination may be compelled to testify. Parts A and B address how judges decide whether testimony might be self-incriminating, and the means by which alternative protections against testimonyaided prosecution are evaluated. Part $\mathrm{C}$ outlines the complications that arise when foreign prosecution is feared.

\footnotetext{
3 Kastigar, 406 US at 453.

4 Hoffman v United States, 341 US 479, 486 (1951). See also Zicarelli v New Jersey State Commission of Investigation, 406 US 472, 479 n 17 (1972).

- See Kastigar, 406 US at 448-49.
} 
A. Determining Whether Testimony Might Be Self-Incriminating

In most cases, deciding whether the testimony sought from a witness might be self-incriminating is rather simple. A judge hearing a motion to compel testimony determines whether the desired disclosures might be "injurious" to the witness, based on the question posed and the context in which it is asked. ${ }^{6}$ This requires the judge to decide whether the testimony sought might possibly be used as, or lead to, evidence that could be introduced in a criminal prosecution of the witness. This procedure is often straightforward because a judge can usually infer from the question and its context whether a response might be self-incriminating.

Occasionally, however, the dangers of testifying are not obvious to the trial judge simply from the question and its context. ${ }^{7}$ In such cases, judges have required witnesses to present, in camera, evidence supporting their claim that the testimony sought might be self-incriminating. ${ }^{8}$ These requests for evidence are designed to elicit the relationship between the desired testimony and the type of criminal charge the witness might face. ${ }^{9}$ Still, judges have been wary about forcing this inquiry too far because it may jeopardize the very protection the privilege is intended to secure. ${ }^{10}$

- Hoffman, 341 US at 486-87; Malloy $v$ Hogan, 378 US 1, 11-12 (1964); Zicarelli, 406 US at 480 .

' See In re Morganroth, 718 F2d 161, 169-70 (6th Cir 1983) (requiring the witness to show how he might be injured by responding to questions he had previously answered); In re Connelly, 59 Bankr 421, 434-35 (Bankr N D IIl 1986) (requiring a debtor in bankruptcy to explain why answering such "seemingly innocuous questions about his residence, prior bankruptcy proceedings, and marital status would pose a real danger of [self-] incrimination").

${ }^{8}$ See McCoy $v$ Commissioner of Internal Revenue, 696 F2d 1234, 1236 (9th Cir 1983). See also Steinbrecher $v$ Commissioner of Internal Revenue, 712 F2d 195, 198 (5th Cir 1983); Fisher $v$ Commissioner of Internal Revenue, 905 F2d 645, 650 (2d Cir 1990).

- See Moses v Allard, 779 F Supp 857, 864 (E D Mich 1991), quoting Morganroth, 718 F2d at 170 ("[Where] questions, on their face and in relation to other facts, appear to call for only innocent answers. ... the court may require that the witness 'supply personal statements under oath or provide evidence with respect to each question propounded to him to indicate the nature of the criminal charge which provides the basis for his fear of prosecution and, if necessary to complement nontestimonial evidence, personal statements under oath to meet the standard for establishing reasonable cause to fear prosecution under this charge." ").

${ }^{20}$ See, for example, Hoffman, 341 US at 486 ("[I]f the witness . . . were required to prove the hazard in the sense in which a claim is usually required to be established in court, he would be compelled to surrender the very protection which the privilege is designed to guarantee."). 
B. Preventing Use of a Witness's Testimony Against Him

Use of a witness's testimony or evidence derived from it to further his domestic criminal prosecution can be prevented by two means other than allowing the witness to remain silent. The much older of these methods involves imposing an absolute bar on prosecution of the witness for any crime about which he is compelled to testify. ${ }^{11}$ This has traditionally taken the form of either a promise from the compelling authorities that they will not prosecute the witness for any crimes about which he testifies, or a law that bars prosecution of the witness for these crimes (that is, a statute of limitations). ${ }^{12}$ The second means by which testimony-aided prosecution may be avoided is by granting the witness use-derivativeuse immunity, which directly prohibits use of the witness's testimony, or any evidence derived from it, in furtherance of his criminal prosecution. ${ }^{13}$ Such immunity can be conferred either by a law that bars authorities from using the testimony against the witness, or by an agreement not to use the testimony against the witness at a later date.

Because no alternative protections are foolproof, however, even the most reliable of assurances cannot eliminate the possibility that a witness's testimony will later be used against him in a criminal prosecution. Nonetheless, the Supreme Court has long held that this risk may be ignored because the probability that a ban on prosecution will be violated without detection by a court is low. ${ }^{14}$ More recently, in Kastigar $v$ United States, the Court approved of use-derivative-use immunity, declaring the protection it provides to be "coextensive with the scope of the privilege against self-incrimination."16 To satisfy the Kastigar "coextensivity" requirement, a government protection need only lower the probability of testimony-aided prosecution below a threshold level; it need not eliminate this probability entirely. Kastigar qualified its endorsement of use-derivative-use immunity, however, by announcing that a government seeking to compel testimony would be required to prove, in a subsequent trial of the witness, that any

12 See generally Brown v Walker, 161 US 591, 597-601 (1896).

12 Criminal prosecution may also be barred by a pardon or the Double Jeopardy Clause. See id at 599; In re Folding Carton Antitrust Litigation, 609 F2d 867, 872 (7th Cir 1979).

13 See Kastigar, 406 US at 453.

14 Brown, 161 US at 608.

15406 US at 453. 
evidence used against him was derived from sources other than the immunized testimony. ${ }^{16}$

C. The Privilege Against Self-Incrimination in Multi-Jurisdictional Cases

Thus far we have seen how fears of future prosecution based on compelled testimony are evaluated and addressed when the compelling jurisdiction and the (would-be) prosecuting jurisdiction are the same. When the compelling and prosecuting jurisdictions are different the inquiry becomes more problematic. This is especially true when the compelling jurisdiction is American and the prosecuting jurisdiction foreign.

When the compelling and prosecuting jurisdictions are different, but both American, determining whether a witness's testimony might incriminate him is fairly easy. This is because all domestic judges are either familiar with the criminal laws of other domestic jurisdictions or easily able to ascertain these laws. By the same token, the traditional protections against prosecution or use of testimony are quite effective in other American jurisdictions. This is a direct result of the Supreme Court's holding in Murphy $v$ Waterfront Commission of New York Harbor that one jurisdiction's grant of protection against prosecution and testimony use automatically prohibits, via the Fifth Amendment, all other jurisdictions from using the witness's testimony against him. ${ }^{17}$

In contrast, when a witness claims that his testimony would be incriminating under the criminal laws of a foreign country, assessing the validity of that claim and providing effective protection are much more difficult. A judge may find himself incapable of readily ascertaining either the applicable foreign law, or how this law should be applied to the witness's case, or both. And Murphy clearly cannot command foreign governments to honor an American jurisdiction's grant of protection against prosecution or use of testimony. In foreign prosecution cases, therefore, the authorities seeking to compel testimony must offer witnesses different forms of protection against testimony-aided prosecution.

\footnotetext{
${ }^{18}$ Id at $460-62$.

${ }^{27} 378$ US 52, 77-78 (1964).
} 


\section{Decisions of the Federal Courts When Foreign Prosecu- TION Is FEARED}

The privilege against self-incrimination cases decided by the federal courts indicate a judicial belief that all witnesses, whether they fear foreign or domestic criminal prosecution, earn the right to remain silent in the same manner. ${ }^{18}$ Yet a closer examination of these cases reveals that in practice witnesses fearing foreign and domestic prosecution have not been burdened equally. ${ }^{19}$ This Section categorizes the decisions of the federal courts in foreign prosecution cases and criticizes the inconsistent ways in which these courts have treated witnesses fearing foreign prosecution. Parts A and $B$ present an overview of the jurisprudence in foreign prosecution cases. Part $\mathrm{C}$ offers specific examples of how the courts suggest that foreign and domestic prosecution cases should be analyzed similarly, yet disadvantage witnesses fearing foreign prosecution relative to their domestic counterparts.

\section{A. The Supreme Court's Jurisprudence}

The Supreme Court has heard only one case in which a witness fearing foreign criminal prosecution has claimed a right of silence under the privilege against self-incrimination. In Zicarelli $v$ New Jersey State Commission of Investigation, ${ }^{20}$ the Court refused to uphold a witness's objection to six questions on the ground that his responses might have incriminated him under foreign law. As to five of these questions, ${ }^{21}$ the Court stated:

These questions do not seek answers concerning foreign involvements or foreign criminal activity. Indeed, they do not relate to criminal acts. Nor is it even remotely likely that their answers could afford "a link. in the chain of evidence" needed to prosecute appellant in a foreign jurisdiction. ${ }^{22}$

18 See Murphy, 378 US at 67-68, 77-78; In re Cardassi, 351 F Supp 1080, 1084-85 (D Conn 1972).

19 See, for example, In re Grand Jury Proceedings (Samuelson), 763 F2d 321, 324 n 4 (8th Cir 1985) (recognizing a "certain tension" between foreign and domestic prosecution cases and suggesting that "a higher standard [is] required to show a real and substantial fear of foreign prosecution").

20406 US 472 (1972).

${ }^{21}$ The five questions were: (1) "Are you a member of any secret organization that is dedicated to or whose principle is to pursue crime and protect those of its members who do commit crime?"; (2) "Do you know that organization by the name Cosa Nostra?"; (3) "Are you a member of the organization known as Cosa Nostra?"; (4) "In whose family of Cosa Nostra are you a member?"; and (5) "Do you know Joseph Bonanno?" Id at 479 n 17.

12 Id. 
And as to the sixth question, ${ }^{23}$ the Court claimed that the witness, without disclosing "information that might incriminate him under foreign law[,] . . . could have answered this question truthfully," even if this required him to "qualify his answer by confining it to domestic [activities]."24

The conclusion in Zicarelli was that the testimony being sought could not incriminate the witness under foreign criminal law. ${ }^{25}$ However, the Court's opinion does not suggest that the Justices found the relevant foreign law troublesome to interpret or apply. Nor does the decision shed any light on how a judge might determine whether the likelihood of testimony-aided foreign prosecution is substantial enough to entitle the witness to remain silent. Therefore, Zicarelli suggests that foreign prosecution cases should be analyzed using the same principles applied in wholly domestic cases.

\section{B. The Decisions of the Circuit Courts}

In the twenty years since the Supreme Court handed down $Z i-$ carelli, the Courts of Appeals have decided numerous privilege against self-incrimination cases involving witnesses fearing foreign prosecution. ${ }^{26}$ For the most part, these courts have agreed with witnesses's assertions that their testimony might be incriminating under foreign law. ${ }^{27}$ Yet only one appellate court has found a likelihood of testimony-aided foreign prosecution to be substantial enough to pose a threat to the witness. ${ }^{28}$ Most courts have instead required witnesses fearing foreign prosecution to testify because of the supposed failure of these witnesses to demonstrate that the

${ }^{23}$ The sixth question was: "In what geographical area do you have Cosa Nostra responsibilities?" Id at 480.

${ }^{24}$ Id at $480-81$.

${ }^{25}$ Id at $478-81$.

${ }^{28}$ See, for example, In re Sealed Case, 825 F2d 494 (DC Cir 1987); In re Quinn, 525 F2d 222 (1st Cir 1975); In re Grand Jury Proceedings (Chevrier), 748 F2d 100 (2d Cir 1984); Environmental Tectonics v W.S. Kirkpatrick Inc., 847 F2d 1052 (3d Cir 1988), affd on other grounds, $110 \mathrm{~S}$ Ct 701 (1990); United States v (Under Seal), 794 F2d 920 (4th Cir 1986); In re Tierney, 465 F2d 806 (5th Cir 1972); United States $v$ Joudis, 800 F2d 159 (7th Cir 1986); In re Baird, 668 F2d 432 (8th Cir 1982); In re Grand Jury Proceeding (Nigro), 705 F2d 1224 (10th Cir 1982); In re Application of the President's Commission (Scaduto), 763 F2d 1191 (11th Cir 1985).

${ }^{27}$ See, for example, Environmental Tectonics, 847 F2d at 1064; Scaduto, 763 F2d at 1198-99.

${ }^{28}$ See Under Seal, 794 F2d at 925-26. 
foreign governments might prosecute them, could obtain custody of them, or could gain access to their testimony. ${ }^{28}$

1. Forms of protection against testimony-aided foreign prosecution.

In order for a witness to be incriminated by his earlier compelled testimony, a prosecuting government must (1) obtain custody of the witness; ${ }^{30}(2)$ gain access to his self-incriminating testimony, or evidence derived from it; (3) criminally prosecute the witness; and (4) use the witness's testimony, or evidence derived from it, to further the prosecution. If any one of these four events cannot occur, the likelihood of testimony-aided prosecution is so low that government authorities should be able to freely compel even self-incriminating testimony. As discussed earlier, of course, the occurrence of these events can never be completely foreclosed because no protections are foolproof. Nevertheless, if the rationale of the Kastigar decision applies in foreign prosecution cases, so long as the likelihood of testimony-aided prosecution is rendered negligible by the protections the government has offered, the witness still may be required to testify.

As in domestic prosecution cases, the testimony of a witness fearing foreign prosecution should be compellable if the witness cannot be prosecuted for the crimes about which he testifies, or if his testimony, or any evidence derived from it, cannot be used against him in such a prosecution. ${ }^{31}$ When the witness fears conviction under foreign law, however, it is the foreign authorities who must agree to, or be legally bound by, alternative protections against either prosecution or testimony use. Thus, a foreign statute of limitations barring prosecution of the witness for the crimes about which he is requested to testify, or a foreign constitutional rule excluding conviction of the witness based on any compelled evidence, might provide adequate protection against testimonyaided prosecution. Alternatively, an agreement by trustworthy for-

20 See, for example, Cheurier, 748 F2d at 104-05; Environmental Tectonics, 847 F2d at 1064-65; Tierney, 465 F2d at 811-12; Joudis, 800 F2d at 163; Baird, 668 F2d at 434; Nigro, 705 F2d at 1227-28; Scaduto, 763 F2d at 1199.

so This event would be unnecessary if the witness could be criminally prosecuted by a foreign government in absentia. However, whether the "criminal case" language of the Fifth Amendment covers in absentia prosecutions is unclear. See Scaduto, 763 F2d at 1199 (holding that the possibility of an in absentia prosecution may be disregarded where its criminal consequences are not explained by the witness).

ar See text accompanying notes 11-13. 
eign officials that they would abide by a grant of use-derivativeuse immunity may suffice for this purpose.

Of course, all protections against foreign prosecution or testimony use are arguably inadequate because their effectiveness depends entirely on enforcement by foreign authorities whose actions cannot be reviewed by the domestic courts that granted the immunity. ${ }^{32}$ This argument, however, cannot be raised with protections that inhibit a foreign government from either obtaining custody of a witness or gaining access to his testimony, since such protections are fully enforceable by domestic authorities. For example, a foreign government can obtain custody of a witness in three ways: extradition, deportation, ${ }^{33}$ and kidnapping. ${ }^{34}$ Yet, extradition and deportation can be fully regulated by federal law or international treaty, while kidnapping can essentially be prevented through institution of a witness protection program.

Similarly, a foreign government can gain access to a witness's testimony, or evidence derived from it, in four ways: (1) required disclosure to the public or in the public record; ${ }^{35}$ (2) disclosure to the foreign government upon a formal request for either information or evidence derived from it; ${ }^{36}$ (3) informal dissemination of the information, whether legal or illegal; or (4) stealing of the in-

32 See Kastigar, 406 US at 460-61 (stating that judicial review of whether a prosecuting government has abided by its agreement not to use the witness's testimony is an important safeguard for a witness).

ss Deportation is only possible where the witness is not a citizen or national of the United States. See Immigration and Nationality Act, 8 USC §§ 1101(a)(3), 1251 (1988 \& Supp II 1990).

s. This statement ignores a fourth contingency that cannot be prevented by means of an alternative protection: voluntary travel to the feared foreign country or to another foreign country from which the feared foreign country may obtain custody of the witness. And though normally a witness's voluntary actions are irrelevant for purposes of the privilege against self-incrimination, compelling testimony would be prohibited if requiring the witness to testify was held to infringe excessively on his constitutional right to travel. See Moses v Allard, 779 F Supp 857, 867 (E D Mich 1991) ("[I]t defies logic to suggest that because, in carrying out the mandates of our judicial system, the Court may place the [witness] in the position where travel to some countries would place her in jeopardy of prosecution or extradition, it therefore may not compel her to answer questions in a domestic [ ] proceeding."). See also Comment, Fear of Foreign Prosecution and the Fifth Amendment, 58 Iowa $L$ Rev 1304, 1320 (1973) (respecting the right to travel in foreign prosecution cases).

${ }^{35}$ Disclosure of a witness's testimony, or evidence derived from it, may be required to further the criminal prosecution or defense of another person. Since criminal defendants are guaranteed the right to a public trial by the Sixth Amendment, In re Oliver, 333 US 257, 271-72 (1948), with the press almost always having the right to attend these trials, Richmond Newspapers, Inc. $v$ Virginia, 448 US 555, 580 (1980), the availability of this testimony to the public seems highly likely absent protective measures taken by the courts.

${ }^{38}$ See, for example, In re Letters Rogatory (Federal Republic of Germany), 448 F Supp 786 (S D Fla 1978). 
formation. Again, the first two of these options may be fully foreclosed by actions of the domestic courts, whereas the latter two options may be substantially obstructed through additional security measures, such as: (1) informing those with access to incriminating evidence of the dangers of its disclosure and requiring these persons to take oaths of secrecy; (2) imposing comprehensive sealing orders on the witness's testimony and limiting access to any incriminating evidence derived from this testimony; and (3) keeping lists of those with access to incriminating evidence and imposing strong sanctions on persons responsible for evidentiary leaks. ${ }^{37}$

2. Protections relied upon by the circuit courts.

In holding that testimony-aided foreign prosecution is a suffciently remote possibility, the circuit courts have relied on permanent protections such as treaties, laws, and judicial orders to prevent foreign governments from obtaining custody of witnesses or access to their testimony. A common holding of these courts has been that the likelihood of foreign prosecution is negligible when extradition of a witness is not provided for by a treaty between the United States and the feared foreign government, or where the offense is not an extraditable offense..$^{38}$ Another line of argument, employed where testimony is being sought by a federal grand jury, has been that Federal Rule of Criminal Procedure 6(e $)^{39}$ provides adequate protection against a witness's testimony being disclosed to foreign authorities. ${ }^{40} \mathrm{And}$, when Rule 6(e) has been inapplicable, comprehensive sealing orders designed to have a similar effect have sometimes been considered satisfactory. ${ }^{41}$

${ }^{37}$ See Cheurier, 748 F2d at 104; Nigro, 705 F2d at 1228.

ss See, for example, Sealed Case, 825 F2d at 497; In re Grand Jury Subpoena (Flanagan), 691 F2d 116, 122 (2d Cir 1982); Environmental Tectonics, 847 F2d at 1064-65; Scaduto, 763 F2d at 1198-99.

39 FRCrP 6(e) provides:

A grand juror, an interpreter, a stenographer, an operator of a recording device, a typist who transcribes recorded testimony, an attorney for the government, or any person to whom disclosure is made under paragraph (3)(A)(ii) of this subdivision shall not disclose matters occurring before the grand jury, except as otherwise provided for in these rules. . . A knowing violation of [this rule] may be punished as a contempt of court.

${ }^{40}$ See, for example, Tierney, 465 F2d at 811; Baird, 668 F2d at 433-34; In re Federal Grand Jury Witness (Lemieux), 597 F2d 1166, 1167 (9th Cir 1979); Nigro, 705 F2d at 1227; In re Grand Jury Proceedings (Perdue), 819 F2d 984, 985-86 (11th Cir 1987). But see Under Seal, 794 F2d at 925 (holding that FRCrP 6(e) would not provide adequate protection).

11 See Joudis, 800 F2d at 163-64. But see Mikutaitis v United States, 478 US 1306, 1309 (1986) (Stevens, Circuit Justice) (suggesting, in an application for a stay of the Joudis 
In the absence of such alternative protections, the courts have presumed a negligible likelihood of foreign prosecution if the foreign authorities have not shown, or are unlikely to show, an interest in prosecuting the witness. For example, when foreign governments have not yet made efforts either to obtain custody of witnesses, or bring criminal charges against them, the likelihood of testimony-aided prosecution has been deemed insubstantial. ${ }^{42}$ The same has been said when foreign governments have not previously sought to prosecute persons for crimes such as those the witness allegedly committed. ${ }^{43}$ When the offenses involved were perpetrated outside territory under control of the foreign governments, the likelihood of testimony-aided prosecution has also been discounted.4

\section{Problems with Existing Federal Jurisprudence}

The decisions of the federal courts imply that the privilege against self-incrimination applies similarly regardless of whether the witness fears foreign or domestic prosecution. But in practice, the courts have repeatedly afforded witnesses fearing foreign and domestic prosecution unequal treatment in three respects. First, they have required a witness fearing foreign prosecution to effectively show not only that his testimony might be self-incriminating, but that it would be self-incriminating. Second, in foreign prosecution cases where the likelihood of testimony-aided prosecution was substantial, the courts have denied a witness's right to remain silent. Finally, the courts have refused to allow a witness fearing foreign prosecution to remain silent until he has demonstrated that he faces a strong likelihood of testimony-aided prosecution, rather than refusing to allow governmental authorities to compel testimony until they have shown that the likelihood of prosecution faced by the witness is negligible. Each of these complaints is discussed below.

decision, that a sealing order might not provide adequate protection because of "the risk that the testimony might be disclosed inadvertently, the fact that the order did not forbid disclosure of evidence derived from the testimony, and the possibility that the [testimony] might be opened at a later date").

4 See United States $v$ Yanagita, 552 F2d 940, 947 (2d Cir 1977); Chevrier, 748 F2d at 103. But see Yues Farms, Inc. v Rickett, 659 F Supp 932, 938 (M D Ga 1987), quoting Cardassi, 351 F Supp at 1085 ("Zicarelli does not appear to require any indication that a foreign prosecution is imminent.").

is See Yanagita, 552 F2d at 946.

"See Quinn, 525 F2d at 223; Flanagan, 691 F2d at 122. 
1. Requiring a greater potential for testimony to be selfincriminating.

A comparison of Zicarelli with a similar domestic case, Hoffman $v$ United States, ${ }^{40}$ illustrates how witnesses fearing foreign criminal prosecution have been required to demonstrate that, relative to their domestic counterparts, their testimony is more likely to be self-incriminating..$^{46}$ In both cases the witnesses were asked several questions pertaining to their occupations and associations. ${ }^{47}$ In Hoffman the Court reversed an order requiring the witness to testify, ${ }^{48}$ while in Zicarelli the court upheld an order compelling testimony. ${ }^{48}$ The Zicarelli Court stated that even if the witness admitted to underworld ties, it "would only confirm an assumption widely held by law enforcement authorities . . . [which] hardly provides a new 'link' to evidence that could be used in a foreign prosecution." "so This approach is inconsistent with the Court's decision in Hoffman, where the witness's objections to questions about his occupation as a racketeer were upheld even though he already had a public reputation for being involved in organized crime, and his name had been placed on a list of "known gangsters." $" 11$

In short, the Zicarelli Court's treatment of witnesses fearing foreign prosecution effectively requires them to demonstrate that their testimony will be, rather than might be, self-incriminating. As mentioned earlier, however, difficulty in ascertaining the relevant foreign law does not appear to be the basis for this decision. ${ }^{62}$ Instead, the Court's concern was probably that if these questions were held impermissible, witnesses, in order to avoid testifying, would falsely claim that their testimony would be self-incriminat-

15341 US 479 (1951).

4 See, for example, Federal Deposit Insurance Corp. v Sovereign State Capital, Inc., 557 F2d 683, 686-87 (9th Cir 1977) (suggesting that Zicarelli might have imposed a more stringent test than Hoffman, but applying the Hoffman standard because the witness was exposed to criminal prosecution in the very jurisdiction wishing to compel testimony).

${ }^{47}$ Compare notes 21 and 23, listing the questions addressed by the Zicarelli Court, with some of the questions confronting the Hoffman Court: (1) "What do you do now, Mr. Hoffman?"; (2) "Have you been doing the same thing you are doing now since the first of the year?"; (3) "When did you last see [Mr. William Weisberg]?"; and (4) "Do you know where Mr. William Weisberg is now?" Hoffman, 341 US at 481.
48 341 US at $489-90$.
406 US at $480-81$.
so Id at $479 \mathrm{n} 17$.
32341 US at 489.
52 See text accompanying note 25 . 
ing under foreign law. ${ }^{83}$ This strategy might be successful because many alternative protections against testimony-aided foreign prosecution fail to satisfy Kastigar's requirement that they be "coextensive with the scope of the privilege against self-incrimination" such that they "suffice[ ] to supplant it." nesses fearing foreign and domestic prosecution are to be afforded analogous treatment-as the decision otherwise suggests-this concern should not have been factored into the Court's analysis.

2. Requiring a greater probability that testimony-aided prosecution will ensue.

In contrast to the Zicarelli Court's focus on the self-incriminating nature of requested testimony, the circuit courts have required witnesses fearing foreign prosecution to testify based on conclusions that these witnesses each faced an insignificant likelihood of testimony-aided prosecution. ${ }^{56}$ If one compares the decisions of these courts to analogous decisions in domestic prosecution cases, these conclusions are questionable on two grounds. First, the circuit courts have often disregarded or severely underestimated the probabilities of several specific ways in which foreign governments might obtain custody of a witness, or access to his testimony or derivative evidence. Second, even when a witness fearing foreign prosecution has faced a likelihood of prosecution that would prevent his testimony from being compelled in domestic cases, the Courts of Appeals have denied these witnesses the right to remain silent.

The first of these errors-the improper disregard of the probability that a foreign government might obtain custody of a witness or gain access to his testimony ${ }^{68}$ - arises in several contexts. For example, in discussing how foreign governments might obtain custody of a witness, the courts have often failed to include

\footnotetext{
${ }^{53}$ See, for example, In re Grand Jury Witness (Gilboe), 699 F2d 71, 75 (2d Cir 1983) (stating that unless courts required "'a particularized showing that the testimony [requested could] incriminate the witness in [a] foreign prosecution' . . . [the] witness might frustrate virtually any criminal investigation with international dimensions simply by pointing to a speculative risk of incrimination in a foreign country"); Moses, 779 F Supp at $864 \mathrm{n}$ 13, quoting Flanagan, $691 \mathrm{~F} 2 \mathrm{~d}$ at 121 (agreeing that a witness "must make a 'particularized showing' that the testimony would be incriminating in a foreign court[, or else] ... the witness 'could use the privilege as a virtual license to frustrate almost any criminal investigation having international consequences, however peripheral or tangential'").

${ }^{54}$ Zicarelli, 406 US at 462.

ss See the cases cited in note 26 .

se For a description of the ways in which a foreign government might obtain custody of a witness or gain access to his testimony, see text accompanying notes 33-36.
} 
meaningful evaluations of the possibility that the witness might be extradited for crimes other than those about which testimony is requested, ${ }^{57}$ or be required to travel to the foreign countries they fear for business or family reasons. ${ }^{58}$ Similarly, with regard to protections against a witness's testimony being disclosed to foreign authorities, several of the appellate courts have deemed FRCrP 6(e) and related sealing orders adequate protection, ${ }^{59}$ despite the fact that such practices have been condemned in wholly domestic cases. ${ }^{60}$ More problematic, however, has been the almost universal disregard by these courts of the possibility that feared foreign authorities might access incriminating evidence derived from compelled testimony. ${ }^{61}$ In Kastigar, the Supreme Court clearly held that the privilege against self-incrimination protects against prosecution by means of derivative evidence as well as actual testimony. ${ }^{62}$

That the circuit courts have required proof of a high probability of prosecution is also evidenced by a case-by-case comparison of how these courts have treated witnesses fearing foreign and domestic prosecution. If anything, the tendency of the appellate courts in wholly domestic cases has been to hold that testimony may not be compelled even when the likelihood of testimony-aided prosecution is minimal. ${ }^{63}$ Yet, where the likelihood of testimony-aided prosecution has seemed high, the circuit courts have almost always required witnesses fearing foreign prosecution to testify. In Environmental Tectonics $v$ W.S. Kirkpatrick Inc., ${ }^{64}$

${ }^{87}$ See, for example, Environmental Tectonics, 847 F2d at 1064-65; Scaduto, 763 F2d at 1198-99. But see Flanagan, 691 F2d at 122 (noting that no evidence supported the witness's claim that he might face extradition for crimes other than those for which he feared immediate foreign prosecution).

st See, for example, Flanagan, 691 F2d at 121-22. But see Sealed Case, 825 F2d at 497 (noting that the witness no longer lived or worked in the feared foreign country and that his immediate family was with him in the United States in holding that the witness's need to travel voluntarily to the foreign country need not be considered).

30 See the cases cited in notes $40-41$.

so See Samuelson, 763 F2d at 324-25; Andover Data Services v Statistical Tabulating Corp., 876 F2d 1080, 1083 (2d Cir 1989).

62 See, for example, cases cited in note 26. But see Under Seal, 794 F2d at 925 (claiming that domestic authorities can offer little protection against a feared foreign government gaining access to evidence derived from a witness's testimony, and holding-notably the only appellate court to do so-that the likelihood of testimony-aided foreign prosecution rendered compelling testimony from the witness sufficiently dangerous).

62406 US at 459-61.

os See, for example, In re Folding Carton Antitrust Litigation (Brown), 609 F2d 867, 872 (7th Cir 1979); In re Master Key Litigation, 507 F2d 292, 293 (9th Cir 1974); United States $v$ Sharp, 920 F2d 1167, 1171 (4th Cir 1990).

at 847 F2d 1052 (3d Cir 1988). 
for example, despite the fact that a United States government official informed the witness he should not travel abroad because foreign authorities were actively seeking to kidnap and prosecute him, the Third Circuit refused to uphold the witness's right to remain silent. ${ }^{65}$ Similarly, In re Baird, ${ }^{66}$ the Eighth Circuit held that a federal grand jury witness, already accused by a foreign government of drug-related offenses, could be compelled to give testimony regarding these alleged crimes based solely on the protection against testimony disclosure afforded by FRCrP 6(e) ${ }^{67}$ On the other hand, in domestic prosecution cases, the appellate courts have protected a witness's right to remain silent based on much weaker evidence; ${ }^{68}$ the appellate directive has always been that "courts should not engage in raw speculation as to whether the government will actually prosecute [a witness]." ${ }^{69}$

3. Placing the burden of persuasion on witnesses rather than on compelling authorities.

With little discussion, the circuit courts have all either held or assumed that a witness fearing foreign prosecution, rather than the authorities seeking the witness's testimony, bears the burden of persuading the court that he faces a substantial likelihood of testimony-aided prosecution. ${ }^{70}$ Those courts paying the most attention to this issue claim simply that such an allocation of the burden of persuasion is required by the Supreme Court's Zicarelli decision. ${ }^{71}$ However, the Zicarelli opinion offers nothing to support such a view; the case contains no discussion of whether the witness must prove the risk of foreign prosecution, or whether the compelling authorities must prove its absence. Furthermore, allocation of the burden of persuasion in this manner conflicts with the generally accepted practice in wholly domestic cases, which is to allow a witness to remain silent until the authorities seeking to compel testimony demonstrate that the witness faces a negligible likelihood of

es Id at 1064-65.

${ }^{\text {Be }} 668$ F2d 432 (8th Cir 1982).

${ }^{67}$ Id at 433-34.

ss See In re Corrugated Container Antitrust Litigation (Conboy), 661 F2d 1145, 115051 (7th Cir 1981), aff'd as Pillsbury Co. v Conboy, 459 US 248 (1983); In re.Corrugated Container Antitrust Litigation (Culy), 662 F2d 875, 884-85 (DC Cir 1981).

's Sharp, 920 F2d at 1171.

30 See the cases cited in note 26.

"1 Yanagita, 552 F2d at 946; Scaduto, 763 F2d at 1198. 
testimony-aided prosecution. ${ }^{72}$ Given the difficulty of accurately establishing likelihoods of testimony-aided prosecution, proving by a preponderance of the evidence that a particular likelihood of prosecution is excessive or negligible may often be impossible.

\section{An Alternative Approach to the Privilege Against Self- INCRIMINATION}

The Supreme Court and the Courts of Appeals are wrong to imply that the privilege against self-incrimination applies equally to all witnesses, while they implement the privilege differently when foreign prosecution is feared. On the other hand, limiting the ability of a witness fearing foreign prosecution to claim the privilege is arguably proper given that the universal application of the standards used in domestic prosecution cases usually would prohibit compulsion of testimony from any witness who asserts a legitimate fear of foreign prosecution. This is true because alternative protections against testimony-aided foreign prosecution generally fail to satisfy the Kastigar "coextensivity" requirement, in that they do not alleviate the likelihood of testimony-aided prosecution as effectively. As a result, not only would the ability of domestic authorities to gather the information they deem necessary for effective operation be impaired, but witnesses would have an incentive to fabricate fears of foreign prosecution in order to avoid testifying.

The underlying mistake of the federal courts, therefore, is not that they have treated witnesses fearing foreign prosecution differently, but rather that they have failed to acknowledge the disparate treatment they are providing. Although society's interest in preventing compulsory self-incrimination is undoubtedly important, the government's interest in gathering needed information and in deterring undue reliance on the privilege deserves respect as well. A reasonable approach to the privilege against self-incrimination requires that these competing interests be balanced against each other. The federal courts have recognized this point, but have incorrectly sought to account for the government's interest in compelling testimony by means of biased evaluations of foreign prose-

72 See Conboy, 661 F2d at 1151; Sharp, 920 F2d at 1171-72. See also Kastigar, 406 US at 462 (holding that use-derivative-use immunity is sufficient to "supplant" the privilege against self-incrimination, thus suggesting that the witness had previously earned the right to remain silent, subject only to the government's ability to regain its right to compel testimony upon a proper showing that the likelihood of testimony-aided prosecution was rendered negligible by the grant of immunity). 
cution claims. Instead, disparate treatment of witnesses fearing foreign prosecution must be firmly grounded in traditional privilege against self-incrimination principles, and the courts must develop clear standards to govern foreign prosecution cases.

This Section explores how the courts might systematically approach the privilege in foreign prosecution cases, so that different treatment of witnesses fearing foreign prosecution can be properly instituted. Part A addresses modification of the inquiry into whether requested testimony might be self-incriminating. Part B discusses alteration of the methods used to determine and evaluate the likelihood of testimony-aided prosecution that witnesses fearing foreign prosecution face. Finally, Part C, after explaining why disparate treatment is appropriate and permissible in foreign prosecution cases, suggests a means of effectuating disparate treatment that avoids many of the problems created by the unprincipled decisions of the federal courts.

A. Determining Whether Testimony Might Be Self-Incriminating When Foreign Prosecution Is Feared

As discussed earlier, if a trial judge must determine whether requested testimony could be self-incriminating under foreign law, he must surmount the significant obstacle of his unfamiliarity with the relevant foreign law. ${ }^{73}$ To address this complication, a witness fearing foreign prosecution should be required to offer additional proof as to the self-incriminating nature of his testimony, as is the case where domestic prosecution is at issue and the self-incriminating potential of the testimony sought is not apparent. ${ }^{74}$ For example, a witness could be required to supply the court with certified and translated copies of any pertinent foreign laws. ${ }^{75}$ When necessary, a court could order presentation of translated foreign judicial opinions, relevant scholarly writings, or expert testimony. ${ }^{76}$ Still, as

7s See text following note 17 .

74 See text accompanying notes 7-9.

${ }^{75}$ Quinn, 525 F2d at 223 (denying the witness the right to invoke the privilege against self-incrimination in part because he had "not identified any [foreign] criminal statute under which he reasonably fears prosecution for conduct to which the questions [asked of him] might relate"). See also Flanagan, 691 F2d at 122; In re Grand Jury Subpoena (Cahalane), 361 F Supp 226, 227 (E D Pa 1973).

${ }^{78}$ See, for example, United States $v$ Klimavicius, 671 F Supp 814, 815 (D Me 1985), rev'd on other grounds, 847 F2d 28 (1st Cir 1988) (discussing a court order that requested the witness to submit "certified, translated copies of the text of all foreign laws which indicate he might be subject to prosecution and to make some showing that the laws would be applied to him if the allegations in the charges against him were proved"); Yanagita, 552 F2d at 946 (suggesting that the witness could have strengthened his claim by pointing to 
in wholly domestic cases, the trial judge must be careful not to require the witness to disclose information that would jeopardize the very protection the privilege seeks to provide.

Aside from the above modifications, the inquiry into whether testimony might be self-incriminating should not differ when foreign prosecution is at issue. Granted, the Zicarelli Court was properly concerned that witnesses fearing foreign prosecution might be able to invoke the privilege against self-incrimination without being entitled to its protection. ${ }^{77}$ However, the potential for such abuse does not stem from difficulty in determining whether testimony might be incriminating under foreign law. Instead, abusive behavior of this type only succeeds because alternative protections against testimony-aided foreign prosecution are ineffective. Therefore, imposition of a higher burden on witnesses fearing foreign prosecution should occur in the context of determining how effective such protections must be to meet the Kastigar "coextensivity" requirement. ${ }^{78}$

B. Preventing the Use of a Witness's Testimony Against Him When Foreign Prosecution Is Feared

Once a witness has demonstrated that the testimony sought from him could be self-incriminating, a court must determine whether the likelihood of testimony-aided prosecution is low enough that the testimony may be compelled anyway. This Part explains how the courts have approached this question in wholly domestic cases and applies these principles to cases involving feared foreign prosecution.

1. Calculating the likelihood of testimony-aided prosecution.

Whenever a witness seeks the protection of the privilege against self-incrimination, a trial judge must follow three steps to calculate the likelihood of testimony-aided prosecution. First, the judge must outline the ways in which the prosecuting authorities may accomplish the four events necessary for testimony-aided prosecution: (1) obtaining custody of the witness; (2) gaining access to his self-incriminating testimony, or evidence derived from it; (3)

cases in which the feared foreign law was interpreted to apply to his situation); Mishima $v$ United States, 507 F Supp 131, 133 (D Alaska 1981) (hearing testimony from an expert on foreign country's law and the application of that law to the witness's situations).

${ }_{72}$ See text accompanying notes 52-54.

78 For a discussion of how this might work in practice, see Section III.C. 
criminally prosecuting him; and (4) using his testimony, or evidence derived from it, to further this prosecution. ${ }^{78}$ Then, based on the outlined ways in which these four events can occur, the judge must estimate the individual probabilities of occurrence for each of these events. Finally, the judge must aggregate these probabilities into an overall assessment of the likelihood that the witness will be subjected to testimony-aided prosecution.

As discussed earlier, one of the ways in which the circuit courts have treated witnesses fearing foreign and domestic prosecution unequally has been in the execution of these three steps. ${ }^{80}$ The appellate courts have systematically underestimated the likelihood of testimony-aided foreign prosecution in order to ensure that domestic authorities are not completely prohibited from obtaining important information, and to deter witnesses from fabricating fears of prosecution under foreign law. Such a practice, however, is an unprincipled response to the issue. Likelihood of prosecution should be assessed accurately; to the extent contrary concerns exist, they are best dealt with by simply admitting that the privilege against self-incrimination affords lesser protection to witnesses fearing foreign prosecution. The federal courts should make certain that all possible paths toward the events necessary for testimony-aided prosecution are considered, that the probabilities these paths might be followed are honestly estimated, and that the overall likelihood of prosecution is determined in an unbiased manner.

2. Determining whether testimony should be compellable.

Once the likelihood of testimony-aided prosecution is calculated, its magnitude must be evaluated to determine whether the witness should be entitled to refrain from testifying. When domestic prosecution is feared, this evaluation is almost always mechanical because most witnesses must be afforded use-derivative-use immunity, ${ }^{81}$ and are then required to testify if so protected. ${ }^{\mathbf{2 2}}$ Given the uncertainties inherent in calculating and evaluating a likelihood of prosecution, this limitation on judicial discretion is undoubtedly appropriate. In foreign prosecution cases, however, limiting discretion in this manner is often impractical because few,

\footnotetext{
70 For a fuller description of these four events, and the several ways in which these events may be brought about, see notes 28-35 and accompanying text.

${ }^{80}$ See text accompanying notes 54-60.

a1 See, for example, Andover Data Services, 876 F2d at 1083.

82 Kastigar, 406 US at 453.
} 
if any, protections can achieve the same level of certainty that use-derivative-use provides in the domestic prosecution context. Thus, the actual likelihood of testimony-aided prosecution is always meaningful when foreign prosecution is feared.

One means of deterring courts from compelling testimony in cases where a witness risks foreign prosecution which would be certain enough to trigger the Fifth Amendment privilege if it were a domestic prosecution instead would be to require the federal courts to assess the likelihood of foreign prosecution with reference to an identifiable threshold standard. By holding that testimony may be compelled from a witness only if the likelihood of testimony-aided prosecution he faces does not exceed the threshold standard, the discretion of the federal courts to trivialize the likelihood of foreign prosecution would be greatly diminished. Eventually, the courts would generate sufficient case law to precisely define the chosen standard, and biased evaluations of a likelihood of prosecution would become almost impossible to disguise.

Adopting a numerical standard, like calculating a numerical likelihood of prosecution, would be impractical. For this reason the standard employed should be situational; for example, the likelihood of prosecution a hypothetical witness faces could be evaluated against the calculated likelihood of prosecution. If a referencing situation is chosen, it should be one in which the likelihood of testimony-aided prosecution borders on being excessively high, but is not constitutionally impermissible. An excellent situation that meets this requirement would be that of a witness facing domestic prosecution, but protected by use-derivative-use immunity which the Court, in Kastigar, only recently held was "coextensive" with the privilege, despite compelling dissents by Justices Douglas and Marshall. ${ }^{83}$ Should the likelihood of prosecution facing an immunized witness be adopted as the threshold standard, evaluation of a claim to the privilege against self-incrimination made by a witness fearing foreign prosecution would then turn on whether the witness faced a greater likelihood of testimony-aided prosecution than does a hypothetical witness protected by such immunity, but who faces authorities intent on prosecuting him, able to obtain custody of him, and able to gain access to his testimony. ${ }^{84}$

ss 406 US at 462 (Douglas dissenting), 467 (Marshall dissenting).

34 See, for example, Andover Data Services, 876 F2d at 1083-84 (weighing the protection afforded by a protective order against that afforded by use-derivative-use immunity in order to determine whether the protective order rendered the likelihood of testimony-aided prosecution negligible). 
Evaluating a likelihood of foreign prosecution by comparing it to the likelihood of an immunized witness's being domestically prosecuted would be quite favorable to a witness fearing foreign prosecution because few, if any, protections against foreign prosecution afford witnesses the same degree of protection that use-derivative-use immunity provides in domestic prosecution cases. Nevertheless, if witnesses fearing foreign prosecution are to be afforded protection commensurate with that afforded to witnesses in domestic cases, as the federal courts have implied is true, only allowing testimony to be compelled when a witness's protections against foreign prosecution are as good as use-derivative-use immunity is in domestic cases seems appropriate. Of course, should the courts decide explicitly that witnesses fearing foreign prosecution are entitled to lesser protection than domestic witnesses, they would be free to choose a different standard of prosecution against which to compare the likelihood of prosecution actually calculated in a case.

3. Allocating burdens of proof in the likelihood of prosecution inquiry.

If the likelihood of testimony-aided prosecution is to be evaluated against a threshold likelihood of prosecution rather than in isolation, the burden of persuading a court that this standard has been exceeded must be allocated. In most domestic prosecution cases allocating the burden of persuasion is unnecessary because the compelling authorities must grant the witness use-derivativeuse immunity, and such protection renders the actual likelihood of prosecution immaterial. In foreign prosecution cases, however, assignment of the burden of persuasion is important because the likelihood of testimony-aided prosecution remains central to whether a witness may be required to testify. As mentioned earlier, given the difficulties in determining the likelihood of prosecution, assignment of this burden takes on special importance as it essentially dictates whether testimony may be compelled. ${ }^{85}$

As discussed previously, the federal courts have deviated from traditional practice by requiring a witness fearing foreign prosecution to prove an excessive likelihood of testimony-aided prosecution, rather than requiring governmental authorities to prove that this likelihood of prosecution is negligible. ${ }^{86}$ Even if this burden of

\footnotetext{
8s See text following note 72 .

${ }^{86}$ See text accompanying notes 69-72.
} 
persuasion should lie with the compelling authorities, however, requiring these authorities to address every conceivable way in which the four events necessary for testimony-aided prosecution possibly might occur may be going too far. To address this concern, the federal courts instead might place a burden on witnesses to first produce evidence suggesting the specific ways in which they fear occurrence of the four necessary events, thus limiting the factual scenarios that the compelling authorities would need to address. This approach also would simplify the judicial determination of whether a compelling government has met its burden by eliminating the need for a judge to decide whether all possible ways in which these events might occur have been considered.

4. Per se rules regarding whether testimony may be compelled.

Once the federal courts have defined the process by which claims to the privilege against self-incrimination are to be evaluated in foreign prosecution cases, judges should constantly seek to simplify this process by characterizing certain protections against testimony-aided prosecution as sufficient and/or necessary. A protection would be sufficient if it renders the likelihood of testimonyaided prosecution a witness faces negligible under all circumstances. In contrast, a protection would be necessary if it must be afforded to a witness, regardless of the actual likelihood of testimony-aided prosecution he faces.

Classifying protections as sufficient allows judges to avoid the time-consuming and often fallible inquiry into whether a witness faces an excessive likelihood of testimony-aided prosecution. Similarly, deeming protections necessary reduces the possibility that judges will mistakenly compel testimony because they have underestimated the actual likelihoods of prosecution. Indeed, the consummate development in domestic prosecution cases has been the classification of use-derivative-use immunity as a sufficient and usually necessary protection, ${ }^{87}$ since this has obviated the need to analyze the likelihood of prosecution in most situations.

Unfortunately, many alternative protections against testimony-aided foreign prosecution cannot be considered sufficient in all situations because they fail to comport with the myriad of for-

\footnotetext{
o7 Use-derivative-use immunity is unnecessary where the witness is safeguarded by another sufficient protection, such as a statute of limitation, an exclusionary rule of evidence, a double jeopardy clause, a pardon, a grant of amnesty, or a grant of transactional immunity.
} 
eign legal systems and practices. Similarly, the classification of protections against foreign prosecution as universally necessary is inconceivable where these protections depend on foreign cooperation for implementation or enforcement. The only viable approach in foreign prosecution cases, therefore, is to classify protections as sufficient and/or necessary in certain well-defined situations.

a) Protections requiring foreign cooperation. An agreement by foreign authorities not to prosecute a witness, or not to use a witness's testimony in furtherance of his prosecution, should never be deemed a sufficient protection. ${ }^{88}$ This is because once these authorities have obtained custody of the witness and gained access to his testimony, they can breach the agreement, and a domestic court could not prevent a testimony-aided prosecution. It was the existence of a judicial safeguard against retractions of this kind that the Kastigar Court relied upon in declaring the suffciency of use-derivative-use immunity. ${ }^{89}$

Admittedly, the above argument also applies to foreign protections of a more permanent nature, such as statutes of limitation, exclusionary rules of evidence, or other foreign laws prohibiting prosecution or testimony use. Yet, many foreign governments may certainly be trusted not to violate these enduring protections for the mere sake of prosecuting a single witness. ${ }^{90}$ Classifying permanent protections as sufficient would therefore be reasonable with respect to governments having a strong history of respect for the rights of accused persons. Indeed, even the Kastigar Court was willing to ignore the arguably comparable probability that a grant of use-derivative-use immunity would be violated without a court's learning of the violation.9

ss This does not imply that a foreign agreement to refrain from prosecution or testimony use would have no value, but rather that this value should be factored into a calculated likelihood of testimony-aided prosecution, which would then dictate whether testimony might be compelled from a witness.

so 406 US at 460 . See also Comment, Self-Incrimination-The Fifth Amendment Protects a Witness Who Refuses to Testify for Fear of Self-Incrimination Under the Laws of a Foreign Jurisdiction, 5 Rutgers-Camden L J 146, 155 (1973) ("[T]he derivative use immunity standards of Murphy ... and Kastigar . . . are predicated upon the availability of post facto judicial control.").

- See Frank Maczko, Obtaining Judicial Assistance in the United States: The Problem of Immunity, 61 Canadian Bar Rev 826, 841 (1983) (suggesting that only statutory immunity from testimony-aided foreign prosecution should be deemed sufficient protection for witnesses fearing foreign prosecution because discretionary assurances of immunity "cannot bind subsequent governments").

${ }^{11} 406$ US at $459-60$. 
b) Domestic protections. Given that foreign governments may obtain custody of witnesses or gain access to their testimony in several different ways, ${ }^{92}$ a sufficient protection against either of these events would have to block all of them simultaneously. Unfortunately, no single protection satisfies this requirement. Sufficiency can therefore only be attained by bundling together enough lesser protections to foreclose every avenue leading to the occurrence of the event in question. With regard to obtaining custody of witnesses, this would require bundled protections against extradition, deportation, and kidnapping. In the case of gaining access to testimony or derivative evidence, such protections would need to prevent public disclosure, disclosure upon foreign request, informal dissemination, and illegal acquisition.

In almost all situations, bundled protections designed to prevent a foreign government from obtaining custody of a witness may reasonably be considered sufficient. ${ }^{93}$ This is because protections against extradition and deportation, the two main paths by which this event might occur, can theoretically always be enforced by a domestic court through the use of injunctive orders prohibiting these practices. ${ }^{94}$ Although kidnapping remains a viable path even when a witness protection program is instituted, it certainly can be disregarded under all but the most extreme circumstances. Paired protections against extradition and deportation, coupled with witness protection when kidnapping poses more than a remote threat, should be deemed sufficient in virtually all situations. ${ }^{95}$

In contrast, protections intended to preclude a foreign government from accessing a witness's testimony, or evidence derived from it, should never be regarded as sufficient. For even assuming complete inhibition of public disclosure, disclosure upon foreign request, and illegal acquisition of a witness's testimony, there remains the most likely path of all: informal dissemination. This path, moreover, never can be blocked by a sufficient protection be-

22 For a description of these paths, see text accompanying notes 33-36.

os In support of this view, see the cases cited in notes $36-38$. See also Gilboe, 699 F2d at 76-77; Yanagita, 552 F2d at 946 n 3; Joudis, 800 F2d at 162-63.

or But see Comment, Extending the Privilege Against Self-Incrimination to the Threat of Prosecution Under Foreign Law, 35 Baylor L Rev 141, 152 (1983) ("[S]ince the extradition process is basically an executive function, it is highly unlikely that the courts would have the constitutional authority to command executive officers not to honor requests for extradition.").

"S Sufficiency could not be declared, however, where the witness's constitutional right to travel would be infringed if he were required to testify. For further discussion of the right to travel question, see note 34 . 
cause once custody of the witness has been obtained by the feared foreign government, a domestic court is powerless to prevent testimony-aided prosecution from taking place should informal dissemination occur. ${ }^{96}$

\section{Different Treatment for Witnesses Fearing Foreign Prosecution}

As asserted throughout this Comment, the federal courts have arguably been correct to distinguish foreign prosecution claims from wholly domestic ones because analyzing foreign claims under traditional standards would severely inhibit the ability of domestic authorities to gather important information, and it would enable many witnesses to fabricate fears of foreign prosecution in order to avoid testifying. ${ }^{97}$ This view is premised on the belief that the purposes of the privilege against self-incrimination require extension of its protection to witnesses fearing foreign prosecution. At the same time, however, such a view clearly rejects the notion that these purposes require identical treatment of witnesses fearing foreign and domestic prosecution. Hence, rather than questioning the extent of protection witnesses fearing foreign prosecution should receive, this Comment takes issue with the unprincipled means by which the federal courts arbitrarily have instituted disparate treatment in foreign prosecution cases.

This Part offers both a constitutional justification for reduced privilege against self-incrimination protection of witnesses fearing foreign prosecution, and a principled means by which the federal courts might establish and implement this lesser form of protection. First, it argues that the privilege should be interpreted as providing some protection in foreign prosecution cases, but that diminished protection, in addition to being correct as a policy matter, is constitutionally permissible. Second, it suggests that any reductions in protection of witnesses fearing foreign prosecution should be accounted for in light of the principles discussed in the prior subsection, and that these reductions should occur only to the extent necessary to protect government's legitimate needs to compel testimony.

${ }^{98}$ See Note, Testimony Incriminating Under the Laws of a Foreign Country-Is There a Right to Remain Silent?, 11 NYU J Intl L \& Pol 359, 381 (1978) ("Grand jury secrecy can not by itself displace the privilege against self-incrimination under either domestic or foreign laws [because it] provides no ex post facto control if the grand jury testimony is divulged ....").

${ }^{97}$ See text accompanying notes 51-52. 
1. Justifying lesser protection in foreign prosecution cases.

Courts and commentators have long debated whether the privilege against self-incrimination acts as a limitation on the very act of compelling self-incriminating testimony from any witness or as a mere restriction on subsequent governmental use of a witness's compelled testimony against him. ${ }^{98}$ Under the "compulsion" approach to the privilege, compulsory self-incrimination is viewed as inappropriate in a society that prides itself on respecting human dignity and privacy. Thus, a witness fearing foreign prosecution would be entitled to protection equal to that provided in domestic prosecution cases, since dignity and privacy are offended regardless of where testimony-aided prosecution subsequently occurs. In contrast, under the "use" approach to the privilege, witnesses fearing foreign prosecution would be afforded no protection whatsoever because the privilege is not violated when the government that uses compelled testimony against a witness is foreign. This restrictive reading of the privilege assumes that its sole purpose is to prevent testimony-aided domestic prosecution, and that extending such protection to foreign prosecution cases would unduly impede the ability of domestic governments to obtain important information from witnesses.

The compulsion/use question has never been explicitly decided by the Supreme Court. Yet in Murphy $v$ Waterfront Commission of New York Harbor, the Court stated that the "compulsion" and "use" rationales are "interrelated facets" of the privilege. ${ }^{99}$ This suggests an alternative approach to the privilege: that it functions to protect witnesses from both "compulsion" and "use." Under this theory, witnesses fearing foreign prosecution would be entitled to some protection by the privilege because compulsory self-incrimination of any kind offends their dignity and privacy. However, since these witnesses would not be facing prose-

\footnotetext{
${ }^{98}$ Compare, for example, Under Seal, 794 F2d at 926-27 (holding that the privilege against self-incrimination does not protect witnesses fearing foreign criminal prosecution because foreign prosecution is not one of those "adverse uses of [ ] compelled testimony . . specifically proscribed by the Fifth Amendment"), with Moses, 779 F Supp at 881 (holding that the privilege against self-incrimination does protect witnesses fearing foreign prosecution because "the compelling body is a court of this nation operating under the American Constitution"). See also Note, The Reach of the Fifth Amendment Privilege When Domestically Compelled Testimony May Be Used in a Foreign Country's Court, 69 Va L Rev 875, 895-97 (1983) (advocating a "use" approach to the privilege); Comment, 5 Rutgers-Camden L J at 164-66 (cited in note 89) (advocating a "compulsion" approach to the privilege).

${ }^{\circ 9} 378$ US 52, 57 n 6 (1964).
} 
cution by domestic authorities, they need not be provided with the high degree of protection afforded in core privilege cases that involve domestic prosecution. ${ }^{100}$

Formal adoption of a two-tiered approach to the privilege against self-incrimination would allow the federal courts to accommodate the government's interests in being able to both obtain important information and deter abusive behavior, while eliminating the need for biased adjudication of foreign prosecution cases. Under pure "compulsion" or "use" theories, balancing these governmental interests against society's interest in preventing possible compulsory self-incrimination is prohibited because a witness must be afforded either protection equal to that conferred in domestic prosecution cases or no protection at all. To achieve a reasonable balance of these competing interests, therefore, the federal courts were essentially required to accept the "compulsion" rationale, but to bias decisions against witnesses fearing foreign prosecution so that only limited protection was conferred on them. In contrast, a two-tiered approach allows competing interests to be balanced without perversion of the privilege against self-incrimination, by affirmatively permitting reduced protection in foreign prosecution cases.

2. Implementing disparate treatment in foreign prosecution cases.

After holding that the disparate treatment of witnesses fearing foreign prosecution is constitutionally permissible, the federal courts would be free to analyze foreign prosecution cases under the privilege against self-incrimination principles established in Part B. Accordingly, disparate treatment in foreign prosecution cases would be accounted for by essentially "raising" the threshold likelihood of prosecution against which calculated likelihoods of prosecution are measured..$^{101}$ This would require selecting a new referencing situation in which the protection the witness was afforded would be considered sufficient under all circumstances. Perhaps such a situation might be where the government has offered assurances that the witness will not be extradited or deported. A wit-

${ }^{100}$ See Comment, 35 Baylor L Rev at 154-55 (cited in note 94) ("To rationally accommodate the rights and interests of both the individual and society, the privilege should be extended to cover the threat of foreign prosecution but with a lower standard of protection so that a governmental body may be able to compel the witness to testify.").

101 For further explanation of the concept of a situational standard, see text accompanying notes 79-80. 
ness fearing foreign prosecution could then be required to testify even where he confronts an actual likelihood of prosecution that would be considered excessive in a domestic prosecution case, so long as the witness's likelihood of prosecution did not exceed the likelihood of a feared foreign government obtaining custody of a hypothetical witness through kidnapping or violation of assurances against extradition or deportation..$^{102}$

Given that the federal courts have sought to provide witnesses fearing foreign prosecution with lesser protection in order to accommodate the government's interests in compelling testimony and deterring abusive claims to the privilege, the extent to which the situational standard is "raised" should depend on a balancing of these interests against society's desire to prevent the possibility of compulsory self-incrimination. As the standard is "raised," the number of witnesses who will face an excessive likelihood of prosecution will decrease, thus expanding the government's ability to gather information and diminishing the prospect of privilege abuse. Care should be taken not to raise the standard too high, however, since at some point testimony-aided prosecution becomes so likely that even governmental interests should yield to the constitutional prohibition of compulsory self-incrimination.

Finally, as an alternative to uniformly changing the threshold likelihood of prosecution against which actual likelihoods of foreign prosecution are measured, the standard might be raised only under certain conditions. Depending on why testimony is being compelled, and how severely the witness would be punished if he eventually faced testimony-aided prosecution, one could employ Kastigar's use-derivative-use immunity standard, or the new extradition and deportation standard. ${ }^{103}$ Thus, where testimony is sought to further a criminal investigation by the compelling government but not where a civil trial is being prepared, the extradition and deportation situation could be adopted. Similarly, if the desired testimony would provide evidence that could not be obtained elsewhere, the new standard could be employed. Lastly, where prospective punishment of the witness would involve a fine

102 But see note 34 for additional concerns regarding the right to travel.

${ }^{103}$ See Comment, 35 Baylor L Rev at 153-54 (cited in note 94) (suggesting that these factors should be considered in determining whether testimony may be compelled from witnesses fearing foreign prosecution). 
or forfeiture rather than incarceration or capital punishment, the special foreign prosecution standard could be utilized. ${ }^{104}$

\section{CoNCLUSION}

The federal courts are justified in placing additional burdens on witnesses claiming the privilege against self-incrimination based on feared foreign prosecution because the government's interests in compelling needed information and deterring fraudulent claims to the privilege should be respected. Furthermore, a two-tiered view of the privilege against self-incrimination is constitutionally permissible because protection of witnesses fearing foreign prosecution is not a core concern of the Fifth Amendment. To ensure that any differences in treatment of witnesses fearing foreign prosecution are properly instituted, however, the means by which the federal courts currently analyze foreign prosecution cases must be abandoned in favor of a standardized approach that operates to constrain judicial discretion. Once courts develop this approach, disparate treatment of witnesses fearing foreign prosecution should be limited to cases in which it is clearly warranted based on a balancing of the compelling government's interest in obtaining testimony against society's interest in avoiding compulsory selfincrimination.

104 See United States $v$ Trucis, 89 FRD 671, 673 (E D Pa 1981) (evaluating the "atrocious nature of the crimes with which [the witness was] charged" in deciding whether he might be compelled to testify). 